\title{
Perfluorocarbon-based oxygen carriers: from physics to physiology
}

\author{
Johannes Jägers $^{1} \cdot$ Anna Wrobeln ${ }^{1} \cdot$ Katja B. Ferenz ${ }^{1,2}$ (D) \\ Received: 21 June 2020 / Revised: 12 October 2020 / Accepted: 16 October 2020 / Published online: 3 November 2020 \\ (C) The Author(s) 2020
}

\begin{abstract}
Developing biocompatible, synthetic oxygen carriers is a consistently challenging task that researchers have been pursuing for decades. Perfluorocarbons (PFC) are fascinating compounds with a huge capacity to dissolve gases, where the respiratory gases are of special interest for current investigations. Although largely chemically and biologically inert, pure PFCs are not suitable for injection into the vascular system. Extensive research created stable PFC nano-emulsions that avoid (i) fast clearance from the blood and (ii) long organ retention time, which leads to undesired transient side effects. PFC-based oxygen carriers (PFOCs) show a variety of application fields, which are worthwhile to investigate. To understand the difficulties that challenge researchers in creating formulations for clinical applications, this review provides the physical background of PFCs' properties and then illuminates the reasons for instabilities of PFC emulsions. By linking the unique properties of PFCs and PFOCs to physiology, it elaborates on the response, processing and dysregulation, which the body experiences through intravascular PFOCs. Thereby the reader will receive a scientific and easily comprehensible overview why PFOCs are precious tools for so many diverse application areas from cancer therapeutics to blood substitutes up to organ preservation and diving disease.
\end{abstract}

Keywords Artificial oxygen carriers · Perfluorocarbon emulsion · Perfluorocarbon-based artificial oxygen carrier · CYP450 uncoupling $\cdot$ Reticuloendothelial system uptake $\cdot$ Perfluorocarbon excretion

\section{Introduction}

Humankind has pursued the idea of rejuvenation and blood substitution since ancient times. In $8 \mathrm{AD}$, Ovid versified his thoughts on the magician Medea who-with a complex mixture of plants, stones and sand she had collected for 9 nights and 9 days - successfully regenerated the blood of the doter Aeson who rejuvenated into a 40-year-old man [45]. The first effective inter-human blood transfusion was performed on September 1st 1818, by James Blundell. But as human blood has always been a very precious and finite good, Amberson and Rhode were among the first researchers mixing isolated red blood cells (RBCs) from cattle, cats, dogs or humans with Ringer's solution to simulate human blood in the 1930s [1]. They focused on the main ability of blood: Oxygen $\left(\mathrm{O}_{2}\right)$

Katja B. Ferenz

katja.ferenz@uk-essen.de

1 University of Duisburg-Essen, Institute of Physiology, University Hospital Essen, Hufelandstraße 55, 45122 Essen, Germany

2 CeNIDE (Center for Nanointegration Duisburg-Essen) University of Duisburg-Essen, Carl-Benz-Strasse 199, 47057 Duisburg, Germany transport via RBCs. It took until the 1960s for the first artificial oxygen carriers made of engineered haemoglobin or other synthetic compounds to replace RBCs in blood substitution. This promised the end of the subjection to donated human blood for transfusion [83]. However, the interest in synthetic blood substitutes only increased gradually until the HI-viruscontaminated-donor-blood-crisis arose in the 1980s and vigorously accelerated the developmental research on artificial blood substitutes [8]. The use of perfluorocarbons bears attractive advantages over blood: Unlimited availability, no transmittance of diseases and no dependence on blood types [23]. This review intends to introduce the reader to these astonishing materials, which offer so many more chances of application beyond ordinary blood substitution.

\section{The very beginning}

The work of Leland C. Clark and Frank Gollan on fluorinated hydrocarbons (perfluorocarbons, PFC) laid the foundation to the idea to utilize the $\mathrm{O}_{2}$ carrying and conducting features of these liquids for clinical application. In their famous experiment in 1966, they made mice dive in fluorobutyltetrahydrofuran (FX- 
80), which was equilibrated with $100 \% \mathrm{O}_{2}$ [9]. Within this experiment, they showed that anaesthetized mammals could breathe this fluid and maintain their respiration for $4 \mathrm{~h}$. In the same publication, they describe their second setup, in which they placed mice under a reverse funnel. The wide side of this funnel was placed under the surface of liquid PFC, which was equilibrated with $100 \% \mathrm{O}_{2}$ so that the only $\mathrm{O}_{2}$ these mice were breathing emerged from the PFC. The mice showed no sign of hypoxia for hours, whereas mice in the same setup with water instead of the PFC died after a few minutes [9]. The latter experiment showed that PFCs are optimal gas transporters as they are not only able to store $\mathrm{O}_{2}$ but also to release enough of it to maintain mammalian life. These key properties gave rise to the idea of using these kinds of chemicals as artificial oxygen carriers in blood substitutes resulting in the first clinical use of a PFCbased artificial oxygen carrier named Fluosol-DA in 1980 [38].

\section{Perfluorocarbons}

PFCs are hydrocarbons whose hydrogen atoms are substituted either completely by fluorine atoms and sometimes additional other halogens (Fig. 1A). This substitution changes the physical properties of these organic compounds radically. Fluorine is the halogen of the second period; its atom radius is only twice the one of hydrogen, while its weight is 20 times the one of hydrogen. Among all the elements, fluorine is the most eager to suck electrons from other atoms, which tightens its bonds along the whole molecular structure and stiffens the carbon backbone of these fluorinated compounds (Fig. 1B)
[88]. The carbon-fluorine bond is very strong $(\sim 484 \mathrm{~kJ} / \mathrm{mol})$ and extremely polar (almost ionic). However, this does not result in water solubility because the intrinsic symmetry annuls the polarity of each $\mathrm{C}-\mathrm{F}$ bond with the whole PFC molecule becoming nonpolar (Fig. 1A). The tight bonds cause a more bulky shape of the PFC molecule so it needs more space in the water, which increases the hydrating energy. This effect decreases the solubility in water, compared to the corresponding hydrocarbon derivative [14]. On the other hand, this extreme polarity inhibits the formation of induced dipoles, which would lead to van der Waals forces, necessary for solubility in lipids. Therefore, PFCs are one of those rare species that are both hydrophobic and lipophobic.

All PFCs are able to dissolve tremendous amounts of gases. The two most commonly used PFCs are perfluorooctylbromide (PFOB) and perfluorodecalin (PFD, Table 1). These two PFCs can dissolve 527 and $403 \mathrm{~mL}_{\mathrm{O} 2} / \mathrm{L}_{\mathrm{PFC}}$ at $1 \mathrm{~atm}(1 \mathrm{bar}$, $713 \mathrm{mmHg}$ ), respectively. Carbon dioxide can be dissolved up to 4 times the amount of $\mathrm{O}_{2}$ [102]. In comparison, the solubility of $\mathrm{O}_{2}$ in water is about 9 to $10 \mathrm{~mL}_{\mathrm{O} 2} / \mathrm{L}_{\text {water }}$ and in blood around $200 \mathrm{~mL} \mathrm{O}_{2} / \mathrm{L}_{\text {blood }}[86,94]$. At this point please be reminded that $1 \mathrm{~L}$ of water contains $55 \mathrm{~mol}$, whereas $1 \mathrm{~L}$ of PFD contains only $4.2 \mathrm{~mol}$. Therefore, the molecular ratio of dissolved $\mathrm{O}_{2}$ is $1_{\mathrm{O} 2}: 200_{\text {water }}$ in water, but $5_{\mathrm{O} 2}: 1_{\mathrm{PFD}}$ in PFD, resulting in a $1000 \times$ increased molecular solubility for PFD compared to water (Fig. 1C). Major properties for these calculations are listed in Table 1.

The low molecule density of PFCs, mentioned above, explains the high $\mathrm{O}_{2}$ capacity and conductivity, which Clark and Gollan tested in their experiment from 1966. Let us carry out a

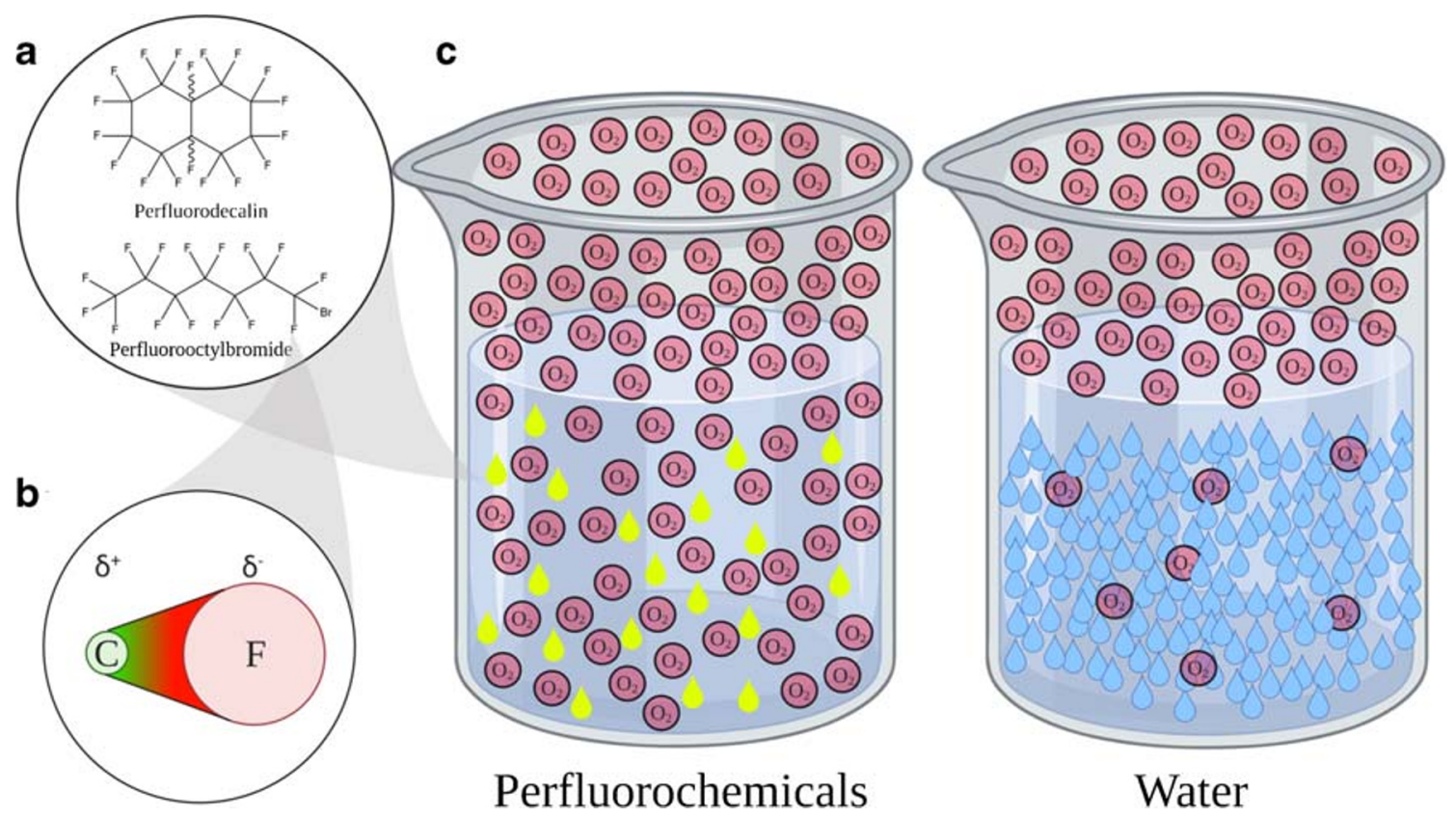

Fig. 1 (A) PFD and PFOB are the most commonly used PFCs as oxygen carriers. (B) The carbon-fluorine-bond is extremely polarized; the probability of the presence of the electron is on the fluorine side. (C) Illustration of the $\mathrm{O}_{2}$ capacity of water and perfluorochemicals. At the same $\mathrm{pO}_{2}$, the amount of $\mathrm{O}_{2}$ dissolved in $\mathrm{PFC}$ is tremendously higher than the amount in water. Figure created with Biorender.com 
Table 1 Comparison of the main physical properties of water, PFD, PFOB and DDFP [42, 94, 102]

\begin{tabular}{|c|c|c|c|c|}
\hline & Water & Perfluorodecalin (PFD) & Perfluorooctylbromide (PFOB) & Dodecafluoropentane (DDFP) \\
\hline Formula & $\mathrm{H}_{2} \mathrm{O}$ & $\mathrm{C}_{10} \mathrm{~F}_{18}$ & $\mathrm{C}_{8} \mathrm{BrF}_{17}$ & $\mathrm{C}_{5} \mathrm{~F}_{12}$ \\
\hline Molar mass & $18 \mathrm{~g} / \mathrm{mol}$ & $462 \mathrm{~g} / \mathrm{mol}$ & $499 \mathrm{~g} / \mathrm{mol}$ & $288 \mathrm{~g} / \mathrm{mol}$ \\
\hline Density & $0.997 \mathrm{~g} / \mathrm{cm}^{3}$ & $1.946 \mathrm{~g} / \mathrm{cm}^{3}$ & $1.89 \mathrm{~g} / \mathrm{cm}^{3}$ & $\begin{array}{l}\left.1.63 \mathrm{~g} / \mathrm{cm}^{3} \text { (liquid, } 25^{\circ} \mathrm{C}\right) \\
0.012 \mathrm{~g} / \mathrm{cm}^{3}\left(\text { gas, } 37^{\circ} \mathrm{C}\right)\end{array}$ \\
\hline Molar density & $55.4 \mathrm{~mol} / \mathrm{L}$ & $4.2 \mathrm{~mol} / \mathrm{L}$ & $3.8 \mathrm{~mol} / \mathrm{L}$ & $0.04166 \mathrm{~mol} / \mathrm{L}$ (gas, $37^{\circ} \mathrm{C}$ ) \\
\hline Oxygen solubility $\left(25^{\circ} \mathrm{C}\right)$ & $6.3 \mathrm{~mL}_{\mathrm{O} 2} / \mathrm{L}_{\mathrm{H} 2 \mathrm{O}}$ & $403 \mathrm{~mL}_{\mathrm{O} 2} / \mathrm{L}_{\mathrm{PFD}}$ & $527 \mathrm{~mL}_{\mathrm{O} 2} / \mathrm{L}_{\mathrm{PFOB}}$ & $29,421 \mathrm{~mL}_{\mathrm{O} 2} / \mathrm{L}_{\mathrm{DDFP}}\left(\mathrm{gas}, 37^{\circ} \mathrm{C}\right)$ \\
\hline Molar oxygen solubility & $0.11 \mathrm{~mL}_{\mathrm{O} 2} / \mathrm{mol}_{\mathrm{H} 2 \mathrm{O}}$ & $95.68 \mathrm{~mL}_{\mathrm{O} 2} / \mathrm{mol}_{\mathrm{PFD}}$ & $139.14 \mathrm{~mL}_{\mathrm{O} 2} / \mathrm{mol}_{\mathrm{PFOB}}$ & $7.06^{*} 10^{5} \mathrm{~mL} / \mathrm{mol}_{\text {DDFP }}\left(\right.$ gas, $\left.37^{\circ} \mathrm{C}\right)$ \\
\hline Molar ratio (oxygen/solute) & $0.005 \mathrm{~mol}_{\mathrm{O} 2} / \mathrm{mol}_{\mathrm{H} 2 \mathrm{O}}$ & $4.27 \mathrm{~mol}_{\mathrm{O} 2} / \mathrm{mol}_{\mathrm{PFD}}$ & $6.21 \mathrm{~mol}_{\mathrm{O} 2} / \mathrm{mol}_{\mathrm{PFOB}}$ & $31.52 \mathrm{~mol}_{\mathrm{O} 2} / \mathrm{mol}_{\mathrm{DDFP}}\left(\mathrm{gas}, 37^{\circ} \mathrm{C}\right)$ \\
\hline
\end{tabular}

thought experiment and consider solvent molecules to be pebbles on a road that you walk on barefoot. You can pass the pebbles, but you need to take your time and energy to carefully step between them. The $\mathrm{O}_{2}$ passes the "PFD pebbles" substantially faster than the "water pebbles", because the PFD molecules leave substantially more space so that the $\mathrm{O}_{2}$ can move freely between the solvent molecules and pass them (Fig. $1 \mathrm{C}$ ). The $\mathrm{O}_{2}$ capacity obeys Henry's law, which means it is theoretically infinite assuming an infinite $\mathrm{pO}_{2}$.

\section{PFC-based oxygen carriers: emulsions, formation and storage}

Less than a year later than their mouse-diving experiment, Clark and Gollan kept a rat Langendorff-heart beating by perfusing it with pure PFC [32]. In 1967, Sloviter annotated in his study: "Water and polar substances such as glucose and salts are virtually insoluble (in PFCs)" [87]. He was the first to emulsify (emulsifier: bovine serum albumin (BSA)) PFC in water and successfully perfuse isolated rat brains [87]. This emulsification paved the way to using PFCs as oxygen carriers in physiological systems by developing a way to allow the addition of, e.g., water-soluble nutrients and pharmaceuticals.

Emulsification is the process of mixing two or more immiscible liquids via building microbubbles. It generates thermodynamically metastable but kinetically stable mixtures. For deeper knowledge about the physics of emulsification, numerous reviews have been published [29, 93]. Briefly, the extreme hydrophobicity of PFCs makes the use of emulsifiers such as lipids, fluorinated compounds, tensides or proteins necessary to bypass the immiscibility with aqueous media, e.g. blood. Forming a microbubble is a thermodynamic process that is described by a variant of the Gibbs-Helmholtz-Equation: [28].

$\Delta G=(\gamma A)-\left(\Delta S^{*} T\right)$

$\Delta G=$ cost of energy (Gibbs-enthalpy), $\gamma=$ interfacial tension, $A=$ interfacial area, $\Delta S=$ gain of disorder (entropy), $T=$ energy (temperature)
The cost of energy (enthalpy) of a reaction must be negative to make the reaction proceeds spontaneously. As you can see in the equation, the interfacial area should be small to minimize the cost of energy. The lack of possible hydrogen bonds at the interface of the immiscible liquids causes interfacial tension, which increases the inner energy of the whole system. However, a few millilitres of an emulsion can contain an interfacial area the size of a football field or even larger. Emulsifiers adhere to the interface and represent a hydrogen bond acceptor that lowers the interfacial tension. This minimizes the unfavourable rise of energy caused by the increase of the interfacial area. Considering the second law of thermodynamics, systems tend to increase the intrinsic disorder. Solving an emulsifier in a solvent, e.g. water, decreases the disorder by forcing the water to form hydration spheres around the emulsifier. Adsorption at interfacial areas, therefore, increases the disorder of the system [27, 93]. As mentioned above, emulsions are metastable because the emulsion reaches the thermodynamic equilibrium only after a complete phase separation, and two major processes push this decay forward. The first one is coalescence. If you have ever observed raindrops running down a window, you might have seen them approaching each other, and as soon as the droplets' surfaces touch, fusing into one big droplet. This event is coalescence and the driving force is the minimization of the interfacial area. The only effective way to avoid the fusion is to avoid the contact between the droplets. One way to accomplish this is to reduce Brownian movement of the droplet via cooling so that the droplets may not move too close to each other. A disadvantage of freezing an emulsion is that it may lead to decay $[16,30]$. Another way to inhibit coalescence is to use charged emulsifiers like lipids or proteins to generate a high surface charge density, which leads to the repulsion of droplets $[48,77]$. To envision this repulsion think of washing your hands with soap. The tensides in the soap give a dense negativity to your skin, which causes the two hands to repulse, leading to reduced friction, which feels slippery [40]. Furthermore, the emulsifier's layer thickness, the emulsifier's density at the interface and the droplet size contribute to the steric stabilization of an emulsion [46]. The repulsion between 
two droplets occurs at distances below twice the layer thickness. The thicker the layer, the earlier the repulsion occurs, which limits the possibility for the attractive forces (van der Waals forces) between two droplets to prevail at short distances. Additionally, the repulsive forces augment with increasing layer-thickness to droplet-size ratio [93]. Therefore, nano-emulsions, which show droplet diameters below $1 \mu \mathrm{m}$, are more stable than micro-emulsions, which exhibit droplet diameters larger than $1 \mu \mathrm{m}$. When the first Food and Drug Administration (FDA)-approved PFC emulsions such as Fluosol-DA and Perftoran came up in the 1980s, they suffered from flocculation, which gave the products weak shelf life [81]. The used emulsifiers were block polymers sometimes mixed with lecithin or phospholipids, which generate too little surface charge density to prevent this process [24]. Freezing the emulsion prior to storage was insufficient because of decay during thawing, which made it necessary to sonicate the emulsion prior to use. Even though these first-generation PFC-based oxygen carriers (PFOCs) showed major physiological side effects, the main reason for stopping the clinical trials in the 1990s was the insufficient shelf life [36, 51, 101]. Short time later, new PFC emulsions such as Oxycyte and Oxygent were developed using egg yolk lecithin as emulsifier and further block polymers (Proxanol 268), which allow for the formation of smaller droplets $(50-100 \mathrm{~nm})$ with a higher charge density $[50,62]$. Those emulsions showed a higher stability, were heat sterilizable and could be stored frozen without decaying when thawing $[23,101]$. Decay of these second-generation emulsions is the result of a second process: Ostwald ripening. Small droplets vanish in favour of the growth of bigger more stable ones. Again, the reduction of the interfacial area is the driving force, but in this case, diminishment by kinetic stabilization is impossible. The PFC inside the droplet evaporates or dissolves in the surrounding solvent until a bigger droplet captures it. Crucial factors herein are the solubility of the PFC in water and its vapour pressure, which forces the PFC to evaporate. Minimizing these factors by choosing the right PFC can minimize Ostwald ripening [43]. Recently developed PFC emulsions using PFD, which displays extremely low solubility in water, can reduce Ostwald ripening. In addition, the use of charged proteins like albumin as an emulsifier that forms a thick layer with a high surface charge density such as in A-AOCs helps to prevent flocculation and coalescence [17, 34].

\section{PFC-based oxygen carriers: droplets under attack}

Entering the vascular system, PFC droplets face different obstacles, which they have to overcome to function as appropriate $\mathrm{O}_{2}$ shuttles. As mentioned above, size is an important factor influencing the stability of emulsions regarding shelf life but also the intravascular half-life [75]. The droplet size should be smaller than $0.5 \mu \mathrm{m}$ mainly because of two reasons. On the one hand, the beneficial effect of the enhanced oxygen transport capacity decreases with increasing size of the droplet, because of reduced diffusivity, so that droplets with a size bigger than $0.5 \mu \mathrm{m}$ need a treatment with $100 \%$ oxygen to work at their full potential [26]. On the other hand, droplets with a diameter over $0.5 \mu \mathrm{m}$ may cause microembolism through obstruction of the microvascular system [104]. Both cause injury by oxygen toxicity and embolism, of the lung for example [80]. Therefore, especially the older formulations (Fluosol-DA and Perftoran) were associated with pneumonia. Additionally, the body is capable of discriminating endogenous and exogenous structures efficiently. Therefore, the body may confuse the droplets with vicious intruders such as microorganisms or tumour cells and might try to defend itself against this alleged danger. The frontline of this defence is the reticuloendothelial system (RES), which consists of several different cell types and proteins. The first step is that complement factors and antibodies recognize the PFC droplets and opsonize them. There are three ways to reduce this process: Firstly, through choosing the adequate emulsifiers such as endogenous proteins and lipids. Secondly, via the attachment of polyethylene glycol (so-called PEGylation) to the outside of the particle, which sterically hinders the general interaction of proteins with the droplet surface $[25,35,52]$. Thirdly, by carefully adjusting the droplet size, which influences the circulation of PFC droplets in the blood. In general, the smaller the droplet, the longer it will circulate in the bloodstream, with a minimum size of around $100 \mathrm{~nm}$, below which the droplets will enter the endothelial cells via pinocytosis $[15,44]$. By saying that, one has to admit that the RES might not be the only factor to explain the elimination from the vascular system. In addition, the fusion of PFCs wrapped in phospholipids with natural lipid vesicles inside the bloodstream may contribute to the particle clearance (Fig. 2C). The rate of this fusion of phospholipid-coated PFC droplets and, e.g., cholesterol vesicles or lipoproteins is proportional to the vapour pressure of the PFC used [53, 99]. Once the droplets are opsonized, circulating macrophages and monocytes take them up and transport them directly to the lung, where they can evaporate [95]. In addition, splenocytes and Kupffer cells also start phagocytosis and, thereby, store the incorporated PFC droplets in the liver (Fig. 2A) and the spleen. Liver damage parameters (aspartate transaminase and alanine transaminase) increase transiently $[6,59,68]$, although the storage of the inherently inert PFC does not cause organ damage per se, except for the formation of foamy cells from primary Kupffer cells (Fig. 2A) $[84,105]$. The increase of plasma transaminase activity seems to be linked to oxidative stress caused by the $\mathrm{O}_{2}$ release from the PFC droplet that occurs inside the macrophages (Fig. 2D) $[4,56]$. Furthermore, once PFC has reached the liver, it starts to uncouple cytochrome P-450 (CYP450) enzyme reactions. The $\mathrm{PFC}$ and the enzyme form a pseudo-enzyme-substrate complex 


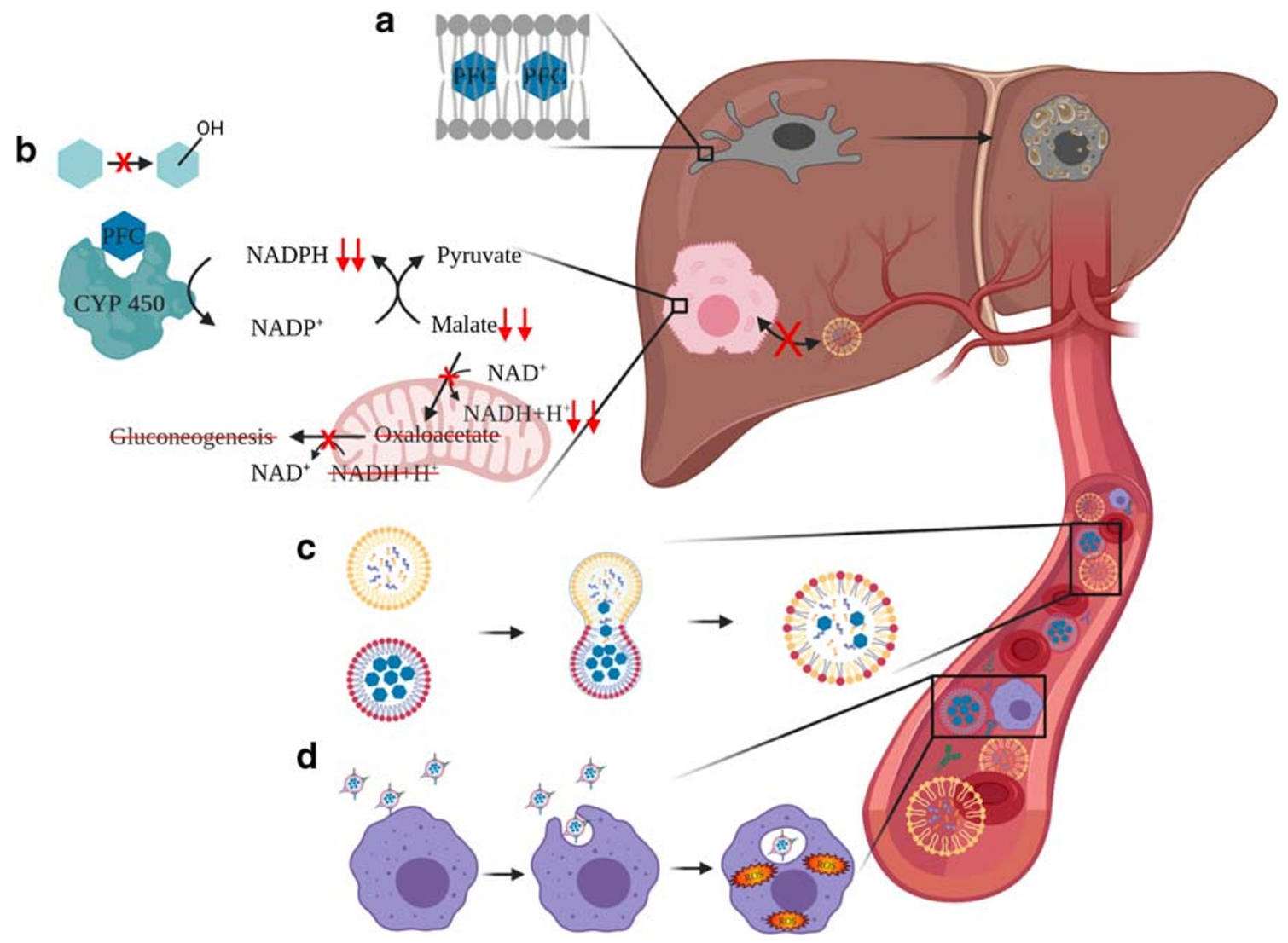

Fig. 2 PFCs are inherently inert, but dependent on their lipo- and hydrophilicity and their vapour pressure they interact with the tissue and blood. (A) Some of the more lipophilic PFCs such as PFOB intercalate into the lipid bilayer of cell and organelle membranes [19]. The major part of PFCs are deposited inside the Kupffer cells which makes them appear foamy [84]. (B) PFCs can uncouple CYP450 monooxygenases, which reduces the detoxification capacity of the liver and causes differed

that leads to the hydrolysis of the coenzyme NADPH without substrate conversion. These enzymes are monooxygenases that bind $\mathrm{O}_{2}$ to potentially poisonous organic compounds to increase their water solubility for renal clearance [96]. The degree of the enzyme-substrate complex formation depends on the lipophilicity of the PFC and impairs the detoxification capacity of the liver $[58,70,73]$. The NADPH depletion causes the malic enzyme to regenerate NADPH at the expense of malate. Subsequently, less malate transforms into oxaloacetate inside the mitochondria, thus producing less $\mathrm{NADH}+\mathrm{H}^{+}$. As a result, oxaloacetate and $\mathrm{NADH}+\mathrm{H}^{+}$are missing for gluconeogenesis (Fig. 2B) [60]. This forces the liver to deplete glycogen [85]. The liver compensates the detoxification impairment by upregulating the CYP450 biosynthesis [60,71]. Furthermore, PFCs lead to a dysregulated lipid storage and utilization in the liver (lack of lipogenesis as well as the inhibition of the uptake of chylomicrons and lipoproteins), which might also result from their CYP450 uncoupling (Fig. 2B) [21, 67, 96]. The organ retention can last up to 130 days, while the PFC is constantly excreted via lipoproteins that transport it to the lung, where it evaporates and leaves the body [18]. In between this long glucose and lipid metabolism [21, 58, 71, 73, 85]. NAD/NADP: Nicotinamideadeninedinucleotide/-phosphate. (C) Proportional to the vapour pressure, phospholipid-wrapped PFCs (red) and natural lipid vesicles (yellow) inside the bloodstream may fuse and form hybrid vesicles $[53,99]$. (D) PFC droplets are opsonized by complement factors or antibodies to be recognized and phagocytized by macrophages [52]. Figure created with Biorender.com

period, the PFC seems to be kept from evaporating. Therefore, one might wonder what is happening inside the organs. With increasing lipophilicity the PFCs tend more to interact with lipid membranes [69]. As mentioned above, the PFCs are generally lipophobic, but, e.g., PFOB displays enough lipophilicity to intercalate into the centre of the lipid bilayers of cell membranes up to $2 \mathrm{~mol} \%$ without causing conformational changes in the membrane (Fig. 2A) [19]. Still, this intercalation is suspected to cause the inhibition of the function of macrophages and neutrophil granulocytes leading to attenuated immune response [72].

\section{PFC-based oxygen carriers: peculiarities and fields of application}

Within the few last years, there has been an important shift of paradigm from large-volume "blood replacement" (several litres) to a small-volume use (mostly $250-500 \mathrm{ml}$ ) of artificial oxygen carriers as "oxygen therapeutics" [23]. The major field of application for PFOCs is clearly the short-term blood 
replacement in cases of blood loss and many reviews already cover this topic $[23,36,41]$. So far, PFOCs can be divided into four subclasses considering the main PFC used in the product: (I) PFD-based PFOCs such as Fluosol-DA, Perftoran and A-AOCs, (II) PFOB-based PFOCs such as Oxygent, (III) tertbutylperfluorocyclohexane-based PFOCs such as Oxycyte and (IV) DDFP-based PFOCs. Their general properties are listed in Table 2. In the USA, the FDA granted the approval for Fluosol-DA in cases of coronary angioplasty but withdrew their approval in 1994 because of its extremely limited shelf life and mainly because of severe complement activation [55]. To treat severe blood loss, Perftoran is approved in Russia, Kazakhstan, Kyrgyzstan and Ukraine and was approved in Mexico from 2005 to 2010 [61]. Oxygent and Oxycyte reached human trials, but by now were not approved by the FDA or elsewhere. Oxycyte successfully completed phase II trials but was abandoned by the sponsor in 2014 due to lack of patient enrolment and economic reasons. Oxygent reached phase III trials, was transiently abandoned because of safety issues that later were disproved to be product-related and is currently under clinical investigation in China [23].

A closer look at the physiological behaviour of blood in the capillaries in comparison to the properties of PFOCs is worthwhile. Because of the Fåhræus-Lindqvist effect in small vessels, RBCs are located in the middle of the bloodstream, surrounded by a cell-free plasma layer. This effect has two consequences leading to enhanced tissue oxygenation in the presence of PFOCs. The first consequence is the so-called plasma skimming, which occurs at bifurcations of the vessels (Fig. 3A). Whenever a vessel splits into smaller vessels of unequal size, the major fraction of the RBCs remain in the larger vessel, thereby reducing the amount of RBCs within the microcirculation. Subsequently, friction is reduced and the flow in microcapillaries is increased. This is necessary to adjust the $\mathrm{O}_{2}$ supply to physiological $\mathrm{O}_{2}$ levels in the tissue [79]. However, pathological obstructions exert a similar influence so that the RBC content of the obstructed vessel decreases disproportionally to the flow. Combined with the low haematocrit, this may amplify tissue hypoxia. Moreover, during shock, a narrowing of vessels occurs as the body centralizes through excessive vasoconstriction, again causing a barrier for RBCs. Such vasoconstriction cannot restrain PFOCs from entering and passing partially obstructed vessels, thus maintaining the $\mathrm{O}_{2}$ supply for the periphery $[13,39]$. Because of the equal distribution of the nano-sized droplets, plasma skimming does not occur with PFC emulsions (Fig. 3B). They maintain the $\mathrm{pO}_{2}$ in the microcirculatory system by passing partially obstructed vessels. Recent preclinical and clinical works on heart attack and stroke showed promising results in minimizing the size of the infarct area and, therefore, extending the window for therapy in acute models $[3,11,12,22,92]$.

The second consequence of the Fåhræus-Lindqvist effect is an increased diffusion distance due to the enlarged cell-free layer surrounding the RBCs [54, 90]. As soon as PFOCs enter the vascular system, they contribute to the $\mathrm{O}_{2}$ capacity of the plasma. The uptake of $\mathrm{O}_{2}$ into the PFC droplet happens faster than the uptake of $\mathrm{O}_{2}$ into the $\mathrm{RBCs}$. This is unimpeded by the emulsifier $[54,106]$. Furthermore, PFOCs stay rather close to the endothelia and shorten the diffusion distance between RBCs and the endothelium whilst acting as stepping-stones for $\mathrm{O}_{2}$ (Fig. 3C) [20, 37, 78]. This facilitated diffusion is helpful in cases of blood loss caused by extensive bleeding or haemodilution, e. g. during operations assisted by heartlung machines [103].

However, PFOCs present exceptional physical and physiological properties (Tables 2 and 3), which differ from those

Table 2 Main properties of the most promising approaches to artificial blood products $[5,12,38,65,80,101,105]$

\begin{tabular}{|c|c|c|c|}
\hline & Formulation & $\begin{array}{l}\text { Mean droplet } \\
\text { size }\end{array}$ & Major side effects \\
\hline Fluosol-DA & $\begin{array}{l}14 \% \text { PFD. } \\
6 \% \text { perfluorotripropylamine }+2.7 \% \text { pluronic } \\
\text { F- } 68+0.4 \% \text { egg yolk phospholipid } \\
\quad+0.03 \% \text { potassium oleate }\end{array}$ & $0.12 \mu \mathrm{m}$ & $\begin{array}{c}\text { Transient drop in neutrophils and } \\
\text { platelets, pneumonia }[74,80]\end{array}$ \\
\hline Perftoran & $\begin{array}{l}14 \% \text { PFD. } \\
6 \% \text { perfluoromethylcyclohexylpiperidin }+6.5 \% \\
\text { proxanol } 268+\text { egg yolk phospholipid }\end{array}$ & $0.03-0.15 \mu \mathrm{m}$ & $\begin{array}{l}\text { Hypotension and pulmonary } \\
\text { complications [61] }\end{array}$ \\
\hline Oxygent & $\begin{array}{l}58 \% \text { PFOB. } \\
2 \% \text { perfluorodecyl bromide }+3.6 \% \\
\quad \text { egg yolk phospholipid }\end{array}$ & $0.16 \mu \mathrm{m}$ & Flu-like symptoms, stroke [49] \\
\hline Oxycyte & $\begin{array}{l}60 \% \text { tertbutylperfluorocyclohexane. } \\
\text { Egg yolk phospholipid }\end{array}$ & $0.2 \mu \mathrm{m}$ & Flu-like symptoms [49] \\
\hline DDFPe & $\begin{array}{l}2 \% \text { DDFP. } \\
5 \% \text { human serum albumin }\end{array}$ & $0.2 \mu \mathrm{m}$ & Coughing, hypertension [12] \\
\hline A-AOCs & $\begin{array}{l}17 \% \text { PFD. } \\
5 \% \text { human serum albumin }\end{array}$ & $0.35 \mu \mathrm{m}$ & $\begin{array}{l}\text { Results of clinical studies are } \\
\text { not yet available [105] }\end{array}$ \\
\hline
\end{tabular}


Fig. 3 (A) RBCs are located in the middle of the bloodstream, surrounded by a cell-free plasma layer. At bifurcations, the RBC concentration decreases (plasma skimming) [79]. (B) The nanosized PFC droplets (light grey) are equally distributed in the vessel and do not rely on plasma skimming [39]. (C) The uptake of $\mathrm{O}_{2}$ into the PFC droplet happens fast, which shortens the diffusion distance between RBCs and endothelium whilst PFC droplets act as stepping-stones for $\mathrm{O}_{2}$ [20].

Figure created with

Biorender.com a

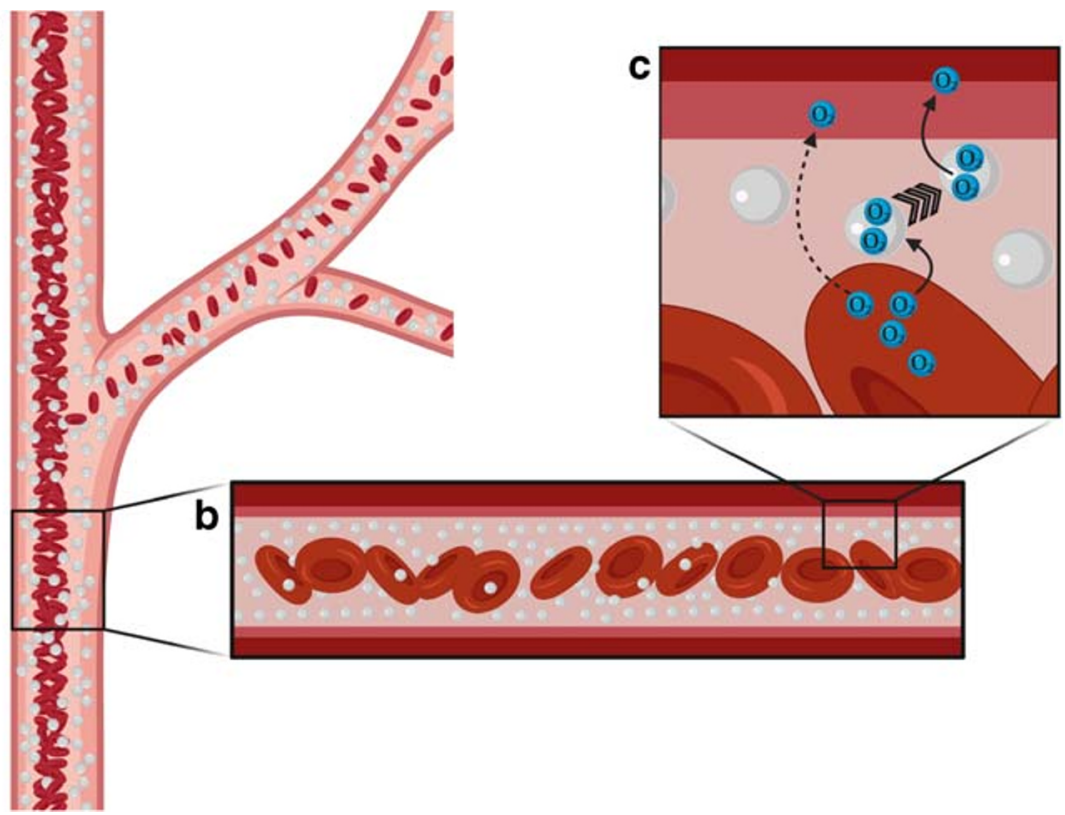

of RBCs, which allows them to stand up particularly well in their use in additional pathological conditions.

One field of application may be the treatment of malignant tumours. Radiotherapy induces the synthesis of reactive oxygen species inside the tumour to cause oxidative stress and finally cell death. Some tumours tend to be metabolically very active so a lack of $\mathrm{O}_{2}$ supply and even anoxia occur in the core of the tumour. This anoxia inhibits the formation of reactive oxygen species and renders the tumour cells resistant to radiation therapy $[31,66]$. Using PFOCs in this context leads to the oxygenation of the whole tumour, including the core, thereby sensitizing the tumour to radiation therapeutics, even if the patients do not breathe pure $\mathrm{O}_{2}$ or carbogen $[33,89,107]$.

In the context of organ transplantation, PFC-based oxygen carriers enable the promising new technology of warm machine perfusion. Thereby the actual static cold storage procedures on ice after flushing with crystalline solutions such as University of Wisconsin solution or Custodiol may be replaced in the future. In the last few years, clinical studies showed the advantage of warm machine perfusion after organ harvest to cold storage, either static or perfused [7, 97]. This technique needs $\mathrm{O}_{2}$ carriers to maintain the physiological status or to regenerate the tissue. Some new attempts show promising results in the ex vivo perfusion of different organs with PFOCs in low doses oxygenated with carbogen or pure $\mathrm{O}_{2}$, respectively $[76,98,106]$. The abovementioned universal gas dissolubility opens another path off the beaten tracks for PFOCs. The inertness towards oxidation permits the transportation of excess carbon monoxide (CO) from the blood to the lung, and the acceleration of the recovery of $\mathrm{CO}$-venomed haemoglobin $[47,105,108]$. In addition, the washout of nitrogen associated with decompression sickness was proven efficient in terms of avoiding embolism in rabbit, pig and rat models [10, $57,63,109]$. Severe nitrogen embolism in rats that underwent simulated diving with fast surfacing could be prevented by infusing albumin-derived PFD oxygen carriers prior to diving [64]. However, PFCs do not only wash out poisonous gases but also balance, e.g., local dysregulated nitrogen monoxide (NO) levels. Russian researchers focused on the use of PFC emulsions as a pharmaceutical for directed transport of endogenous bioactive $\mathrm{NO}$ to regulate cardiovascular complications associated with $\mathrm{NO}$ imbalance [82].

In the 1990s, another field of application for PFC emulsions — use as a contrast agent—was discovered exploiting their ultrasound absorbing properties. DDFP was chosen for this purpose, because of its low boiling point $\left(28^{\circ} \mathrm{C}\right)$, which permits phase transition from the liquid into the gaseous phase, immediately after intravenous injection. The gaseous form results in an extremely short blood half-life of $1.45 \pm 0.17 \mathrm{~min}$ and a main
Table 3 Physical and physiological features of PFOCs in comparison to RBCs

\begin{tabular}{lll}
\hline & RBCs & PFOCs \\
\hline Gas transport & Chemically bound & $\begin{array}{l}\text { Physically dissolved } \\
\text { Gases }\end{array}$ \\
Size & $\mathrm{O}_{2}, \mathrm{CO}_{2}$-sensitive to oxidative gases & $\begin{array}{l}\text { Universal gas dissolubility regardless to } \\
\text { oxidative properties }\end{array}$ \\
Microcirculation & $8000-10,000 \mathrm{~nm}$ & $\sim 200 \mathrm{~nm}$ (nano-scaled) \\
\hline
\end{tabular}


excretion route via the lung, which minimizes organ retention of DDFP and therefore its negative side effects $[2,12]$. These properties of DDFP are in extreme contrast to the other PFCs mentioned above, normally aiming at a rather long intravascular halflife, when PFC emulsions are used as blood substitutes [42]. Nevertheless, DDFPe qualifies as an artificial oxygen carrier therapeutic as the transition leads to a tremendous expansion of intermolecular cavities resulting in an oxygen capacity superior to all other PFCs (Table 1). One application is the short-term oxygenation of hypoxic tissue after stroke [11-13]. Furthermore, DDFP emulsions (DDFPe) can be used for tissue preconditioning prior to a surgery involving tissue ischaemia (e.g. myocard); a technique used to decrease infarct volume during stroke. Here, intravenous administration of DDFPe functions as an oxygen tidal wave resulting in production of reactive oxygen species which is acute but limited in time. These reactive oxygen species subsequently activate the mitochondrial ATP-sensitive $\mathrm{K}^{+}$-channel, an effect that exceeds intravascular half-life of DDFPe [11-13, 91].

The current year 2020 presents a major obstacle for humankind in a form of a pandemic that causes thousands to die and millions to be kept in quarantine. The use of PFOCs to treat COVID-19 patients has not yet been tested. However, their use as an additional $\mathrm{O}_{2}$ transporter to enhance the peripheral $\mathrm{O}_{2}$ supply even in narrowed microcapillaries during severe lung inflammation and their cytoprotective effect on RBCs are already discussed [100].

\section{Conclusion}

Researchers aiming to develop biocompatible artificial oxygen carriers have to work extremely interdisciplinary. More than 50 years after L. C. Clark's first experiments, researchers worldwide still work in different fields to obtain more and more knowledge on PFOCs. Hopefully, this will lead to safe PFC formulations and allow to exploit these materials to a greater extent as universal gas transporters. The former sprint in the 80 s has turned into a marathon because of the complexity of simulating blood. Researchers are still developing new applications and promising new formulations, which make the research field of PFOCs more topical than ever.

Acknowledgments Open Access funding enabled and organized by Projekt DEAL.

Authors' contributions - Idea and conceptualization: Johannes Jägers, Katja Bettina Ferenz

- Writing, reviewing and editing: Johannes Jägers, Anna Wrobeln, Katja Bettina Ferenz

- Literature research: Johannes Jägers, Anna Wrobeln, Katja Bettina Ferenz

- Figure conceptualization and design: Johannes Jägers, Anna Wrobeln
Data availability Not applicable.

\section{Compliance with ethical standards}

Conflict of interest The authors declare that they have no conflict of interest.

Ethics approval Not applicable.

Consent to participate Not applicable.

Consent for publication Not applicable.

Code availability Not applicable.

Open Access This article is licensed under a Creative Commons Attribution 4.0 International License, which permits use, sharing, adaptation, distribution and reproduction in any medium or format, as long as you give appropriate credit to the original author(s) and the source, provide a link to the Creative Commons licence, and indicate if changes were made. The images or other third party material in this article are included in the article's Creative Commons licence, unless indicated otherwise in a credit line to the material. If material is not included in the article's Creative Commons licence and your intended use is not permitted by statutory regulation or exceeds the permitted use, you will need to obtain permission directly from the copyright holder. To view a copy of this licence, visit http://creativecommons.org/licenses/by/4.0/.

\section{References}

1. Amberson WR, Mulder AG, Steggerda FR, Flexner J, Pankratz DS (1933) Mammalian life without red blood corpuscles. Science 78:106-107. https://doi.org/10.1126/science.78.2014.106

2. Arthur C, Song L, Culp W, Brown A, Borrelli M, Skinner R, Hendrickson H (2017) Tissue concentration of dodecafluoropentane (DDFP) following repeated IV administration in the New Zealand white rabbit. AAPS J 19:520-526. https:// doi.org/10.1208/s12248-016-0013-0

3. Brown AT, Arthur MC, Nix JS, Montgomery JA, Skinner RD, Roberson PK, Borrelli M, Culp WC (2014) Dodecafluoropentane emulsion (DDFPe) decreases stroke size and improves neurological scores in a permanent occlusion rat stroke model. Open Neurol J 8:27-33. https://doi.org/10.2174/ 1874205x01408010027

4. Bucala R, Kawakami M, Cerami A (1983) Cytotoxicity of a perfluorocarbon blood substitute to macrophages in vitro. Science 220:965-967. https://doi.org/10.1126/science.6844922

5. Castro CI, Briceno JC (2010) Perfluorocarbon-based oxygen carriers: review of products and trials. Artif Organs 34:622-634. https://doi.org/10.1111/j.1525-1594.2009.00944.x

6. Castro O, Nesbitt AE, Lyles D (1984) Effect of a perfluorocarbon emulsion (Fluosol-DA) on reticuloendothelial system clearance function. Am J Hematol 16:15-21. https://doi.org/10.1002/ajh. 2830160103

7. Chandak P, Phillips BL, Uwechue R, Thompson E, Bates L, Ibrahim I, Sewpaul A, Figueiredo R, Olsburgh J, Hosgood S (2019) Dissemination of a novel organ perfusion technique: ex vivo normothermic perfusion of deceased donor kidneys. Artif Organs 43:E308-E319. https://doi.org/10.1111/aor.13499

8. Chang TM (2012) From artificial red blood cells, oxygen carriers, and oxygen therapeutics to artificial cells, nanomedicine, and 
beyond. Artif Cells Blood Substit Immobil Biotechnol 40:197199. https://doi.org/10.3109/10731199.2012.662408

9. Clark LC, Gollan F (1966) Survival of mammals breathing organic liquids equilibrated with oxygen at atmospheric pressure. Science 152:1755-1756. https://doi.org/10.1126/science.152. 3730.1755

10. Cronin WA, Hall AA, Auker CR, Mahon RT (2018) Perfluorocarbon in delayed recompression with a mixed gender swine model of decompression sickness. Aerosp Med Human Perform 89:14-18. https://doi.org/10.3357/AMHP.4925.2018

11. Culp WC, Brown AT, Lowery JD, Arthur MC, Roberson PK, Skinner RD (2015) Dodecafluoropentane emulsion extends window for tPA therapy in a rabbit stroke model. Mol Neurobiol 52: 979-984. https://doi.org/10.1007/s12035-015-9243-x

12. Culp WC, Onteddu SS, Brown A, Nalleballe K, Sharma R, Skinner RD, Witt T, Roberson PK, Marsh JD (2019) Dodecafluoropentane emulsion in acute ischemic stroke: a phase $\mathrm{Ib} / \mathrm{II}$ randomized and controlled dose-escalation trial. J Vasc Interv Radiol 30:1244-1250.e1241. https://doi.org/10.1016/j. jvir.2019.04.020

13. Culp WC, Woods SD, Skinner RD, Brown AT, Lowery JD, Johnson JL, Unger EC, Hennings LJ, Borrelli MJ, Roberson PK (2012) Dodecafluoropentane emulsion decreases infarct volume in a rabbit ischemic stroke model. J Vasc Interv Radiol 23:116121. https://doi.org/10.1016/j.jvir.2011.10.001

14. Dalvi VH, Rossky PJ (2010) Molecular origins of fluorocarbon hydrophobicity. Proc Natl Acad Sci 107:13603-13607. https:// doi.org/10.1073/pnas.0915169107

15. Dawson KA, Salvati A, Lynch I (2009) Nanoparticles reconstruct lipids. Nat Nanotechnol 4:84-85. https://doi.org/10.1038/nnano. 2008.426

16. Degner BM, Chung C, Schlegel V, Hutkins R, McClements DJ (2014) Factors influencing the freeze-thaw stability of emulsionbased foods. Compr Rev Food Sci Food Saf 13:98-113. https:// doi.org/10.1111/1541-4337.12050

17. Dichiarante V, Milani R, Metrangolo P (2018) Natural surfactants towards a more sustainable fluorine chemistry. Green Chem 20: 13-27. https://doi.org/10.1039/c7gc03081a

18. Doronina N, Kurmacheva O, Afonin N (1994) Effect of perfluorochemical emulsion on lipoproteins of plasma blood. Artif Cells Blood Substit Biotechnol 22:1295-1298. https://doi. org/10.3109/10731199409138829

19. Ellena JF, Obraztsov VV, Cumbea VL, Woods CM, Cafiso DS (2002) Perfluorooctyl bromide has limited membrane solubility and is located at the bilayer center. Locating small molecules in lipid bilayers through paramagnetic enhancements of NMR relaxation. J Med Chem 45:5534-5542. https://doi.org/10.1021/ jm020278x

20. Faithfull NS (1992) Oxygen delivery from fluorocarbon emulsions-aspects of convective and diffusive transport. Biomater Artif Cell Immobil Biotechnol 20:797-804. https:// doi.org/10.3109/10731199209119721

21. Fang X, Gao G, Xue H, Zhang X, Wang H (2012) In vitro and in vivo studies of the toxic effects of perfluorononanoic acid on rat hepatocytes and Kupffer cells. Environ Toxicol Pharmacol 34: 484-494. https://doi.org/10.1016/j.etap.2012.06.011

22. Ferenz KB (2020) Artificial oxygen carriers. In: Current trends and future developments on (bio-) membranes. Elsevier, pp 191213. doi:https://doi.org/10.1016/B978-0-12-814225-7.00008-5

23. Ferenz KB, Steinbicker AU (2019) Artificial oxygen carrierspast, present, and future - a review of the most innovative and clinically relevant concepts. J Pharmacol Exp Ther 369:300 310. https://doi.org/10.1124/jpet.118.254664
24. Ferenz KB, Waack IN, Laudien J, Mayer C, Broecker-Preuss M, de Groot H, Kirsch M (2014) Safety of poly (ethylene glycol)coated perfluorodecalin-filled poly (lactide-co-glycolide) microcapsules following intravenous administration of high amounts in rats. Results Pharma Sci 4:8-18. https://doi.org/10.1016/j. rinphs.2014.04.001

25. Ferenz KB, Waack IN, Mayer C, de Groot H, Kirsch M (2013) Long-circulating poly(ethylene glycol)-coated poly(lactid-coglycolid) microcapsules as potential carriers for intravenously administered drugs. J Microencapsul 30:632-642. https://doi.org/10. 3109/02652048.2013.770098

26. Fraker CA, Mendez AJ, Inverardi L, Ricordi C, Stabler CL (2012) Optimization of perfluoro nano-scale emulsions: the importance of particle size for enhanced oxygen transfer in biomedical applications. Colloids Surf B: Biointerfaces 98:26-35. https://doi.org/ 10.1016/j.colsurfb.2012.04.011

27. Freire MG, Carvalho PJ, Queimada AJ, Marrucho IM, Coutinho JA (2006) Surface tension of liquid fluorocompounds. J Chem Eng Data 51:1820-1824. https://doi.org/10.1021/je060199g

28. Freire MG, Dias AM, Coelho MA, Coutinho JA, Marrucho IM (2005) Aging mechanisms of perfluorocarbon emulsions using image analysis. J Colloid Interface Sci 286:224-232

29. Fryd MM, Mason TG (2012) Advanced nanoemulsions. Annu Rev Phys Chem 63:493-518. https://doi.org/10.1146/annurevphyschem-032210-103436

30. Ghosh S, Coupland JN (2008) Factors affecting the freeze-thaw stability of emulsions. Food Hydrocoll 22:105-111. https://doi. org/10.1016/j.foodhyd.2007.04.013

31. Glass SB, Gonzalez-Fajardo L, Beringhs AOR, Lu X (2019) Redox potential and ROS-mediated nanomedicines for improving cancer therapy. Antioxid Redox Signal 30:747-761. https://doi. org/10.1089/ars.2017.7370

32. Gollan F, Clark L (1966) Organ perfusion with fluorocarbon fluid. Physiologist 9:H292

33. Graham K, Unger E (2018) Overcoming tumor hypoxia as a barrier to radiotherapy, chemotherapy and immunotherapy in cancer treatment. Int J Nanomedicine 13:6049-6058. https://doi.org/10. 2147/ijn.S140462

34. Haque ZA, Kinsella JO (1988) Emulsifying properties of food proteins: bovine serum albumin. J Food Sci 53:416-420. https:// doi.org/10.1111/j.1365-2621.1988.tb07719.x

35. Harris JM, Martin NE, Modi M (2001) Pegylation. Clin Pharmacokinet 40:539-551. https://doi.org/10.2165/00003088200140070-00005

36. Hill SE (2019) Perfluorocarbons: knowledge gained from clinical trials. Shock 52:60-64. https://doi.org/10.1097/SHK. 0000000000001045

37. Homer L, Weathersby P, Kiesow L (1981) Oxygen gradients between red blood cells in the microcirculation. Microvasc Res 22: 308-323. https://doi.org/10.1016/0026-2862(81)90099-6

38. Honda K, Hoshino S, Shoji M, Usuba A, Motoki R, Tsuboi M, Inoue $\mathrm{H}$, Iwaya $\mathrm{F}$ (1980) Clinical use of a blood substitute. $\mathrm{N}$ Engl J Med 303:391-392. https://doi.org/10.1056/ nejm198008143030710

39. Ryzhkov IA, Zarzhetsky YV, Novoderzhkina IS (2015) Effect of perfluorane on the regulation of skin blood flow in acute blood loss: experimental study. General Reanimatology 11:19-27. https://doi.org/10.15360/1813-9779-2015-6-19-27

40. Idson B (1967) Adsorption to Skin and Hair. J Cosmet Sci :91103. doi:10.1.1.492.6875

41. Jahr JS, Guinn NR, Lowery DR, Shore-Lesserson L, Shander A (2019) Blood substitutes and oxygen therapeutics: a review. Anesth Analg. https://doi.org/10.1213/ANE.0000000000003957 
42. Johnson JL, Dolezal MC, Kerschen A, Matsunaga TO, Unger EC (2009) In vitro comparison of dodecafluoropentane (DDFP), perfluorodecalin (PFD), and perfluoroctylbromide (PFOB) in the facilitation of oxygen exchange. Artif Cells Blood Substit Biotechnol 37:156-162. https://doi.org/10.1080/ 10731190903043192

43. Kabalnov A, Makarov K, Shcherbakova O, Nesmeyanov A (1990) Solubility of fluorocarbons in water as a key parameter determining fluorocarbon emulsion stability. J Fluor Chem 50: 271-284. https://doi.org/10.1016/S0022-1139(00)84993-3

44. Keipert P, Otto S, Flaim S, Weers J, Schutt E, Pelura T, Klein D, Yaksh T (1994) Influence of perflubron emulsion particle size on blood half-life and febrile response in rats. Artif Cells Blood Substit Biotechnol 22:1169-1174. https://doi.org/10.3109/ 10731199409138812

45. Kline AS (2000) Ovid's metamorphoses, book 7 rhymes 234-293. The Ovid Collection - University of Virginia Library. https:/ovid. lib.virginia.edu/trans/Metamorph7.htm Accessed 20 June 2020

46. Kohler J, Ruschke J, Ferenz KB, Esen C, Kirsch M, Ostendorf A (2018) Investigation of albumin-derived perfluorocarbon-based capsules by holographic optical trapping. Biomed Opt Express 9:743-754. https://doi.org/10.1364/BOE.9.000743

47. Kozlova E, Chernysh A, Moroz V, Sergunova V, Zavialova A, Kuzovlev A (2016) Nanoparticles of perfluorocarbon emulsion contribute to the reduction of methemoglobin to oxyhemoglobin. Int J Pharm 497:88-95. https://doi.org/10.1016/j.ijpharm.2015.11. 035

48. Kumar A, Dixit CK (2017) Methods for characterization of nanoparticles. In: Advances in nanomedicine for the delivery of therapeutic nucleic acids. pp. 43-58. doi:https://doi.org/10.1016/b9780-08-100557-6.00003-1

49. Lambert E, Gorantla VS, Janjic JM (2019) Pharmaceutical design and development of perfluorocarbon nanocolloids for oxygen delivery in regenerative medicine. Nanomedicine 14:2697-2712. https://doi.org/10.2217/nnm-2019-0260

50. Latson GW (2019) Perftoran (Vidaphor) - introduction to western medicine. Shock 52:65-69. https://doi.org/10.1097/SHK. 0000000000001063

51. Laudien J, Groß-Heitfeld C, Mayer C, de Groot H, Kirsch M, Ferenz KB (2015) Perfluorodecalin-filled poly (n-butyl-cyanoacrylate) nanocapsules as potential artificial oxygen carriers: preclinical safety and biocompatibility. J Nanosci Nanotechnol 15:56375648. https://doi.org/10.1166/jnn.2015.10044

52. Leal-Calderon F, Cansell M (2012) The design of emulsions and their fate in the body following enteral and parenteral routes. Soft Matter 8:10213-10225. https://doi.org/10.1039/C2SM26215K

53. Lee S-J, Schlesinger PH, Wickline SA, Lanza GM, Baker NA (2012) Simulation of fusion-mediated nanoemulsion interactions with model lipid bilayers. Soft Matter 8:7024-7035. https://doi. org/10.1039/C2SM25847A

54. Lowe KC (2003) Engineering blood: synthetic substitutes from fluorinated compounds. Tissue Eng 9:389-399. https://doi.org/ $10.1089 / 107632703322066570$

55. Lowe KC (2006) Blood substitutes: from chemistry to clinic. J Mater Chem 16:4189-4196. https://doi.org/10.1039/B604923K

56. Lutz J, Decke B, Bäuml M, Schulze H-G (1978) High oxygen extraction combined with extensive oxygen consumption in the rat liver perfused with fluosol-DA R, a new perfluoro compound emulsion. Pflugers Arch 376:1-6. https://doi.org/10.1007/ BF00585240

57. Lutz J, Herrmann G (1984) Perfluorochemicals as a treatment of decompression sickness in rats. Pflugers Arch 401:174-177. https://doi.org/10.1007/BF00583878
58. Lutz J, Krafft MP (1997) Longitudinal studies on the interaction of perfluorochemicals with liver cytochromes P-450 by means of testing the rate of detoxification of pentobarbital. In: Nemoto EM, LaManna JC, Cooper C et al (eds) Oxygen transport to tissue XVIII. Springer US, Boston, pp 391-394. https://doi.org/10.1007/ 978-1-4615-5865-1_50

59. Lutz J, Metzenauer P (1980) Effects of potential blood substitutes (perfluorochemicals) on rat liver and spleen. Pflugers Arch 387: 175-181. https://doi.org/10.1007/BF00584269

60. Maevsky E, Ivanitsky G (2005) Oxygen-dependent and oxygenindependent effects of Perftoran. In: Kobayashi K (ed) Artificial oxygen carrier - its front line. Artificial Oxygen Carrier. Springer Tokyo, Tokyo, pp 221-228. https://doi.org/10.1007/4-43126651-8 17

61. Maevsky E, Ivanitsky G, Bogdanova L, Axenova O, Karmen N, Zhiburt E, Senina R, Pushkin S, Maslennikov I, Orlov A (2005) Clinical results of Perftoran application: present and future. Artif Cells Blood Substit Biotechnol 33:37-46. https://doi.org/10.1081/ BIO-200046654

62. Magdassi S, Siman-Tov A (1990) Formation and stabilization of perfluorocarbon emulsions. Int J Pharm 59:69-72. https://doi.org/ 10.1016/0378-5173(90)90065-C

63. Mayer D, Ferenz KB (2019) Perfluorocarbons for the treatment of decompression illness: how to bridge the gap between theory and practice. Eur J Appl Physiol 119:2421-2433. https://doi.org/10. 1007/s00421-019-04252-0

64. Mayer D, Guerrero F, Goanvec C, Hetzel L, Linders J, Ljubkovic M, Kreczy A, Mayer C, Kirsch M, Ferenz KB (2020) Prevention of decompression sickness by novel artificial oxygen carriers. Med Sci Sports Exerc 52(10):2127-2135. https://doi.org/10. 1249/mss.0000000000002354

65. Mitsuno T, Ohyanagi H, Naito R (1982) Clinical studies of a perfluorochemical whole blood substitute (Fluosol-DA) summary of 186 cases. Ann Surg 195:60-69. https://doi.org/10.1097/ 00000658-198201001-00010

66. Moulder JE, Rockwell S (1987) Tumor hypoxia: its impact on cancer therapy. Cancer Metastasis Rev 5:313-341. https://doi. org/10.1007/BF00055376

67. Nagata Y, Mondon CE, Cooper AD (1990) The effect of perfluorochemical artificial blood on lipoprotein metabolism in rats. Metab Clin Exp 39:682-689. https://doi.org/10.1016/00260495(90)90101-h

68. Nieuwoudt M, Engelbrecht GH, Sentle L, Auer R, Kahn D, van der Merwe SW (2009) Non-toxicity of IV injected perfluorocarbon oxygen carrier in an animal model of liver regeneration following surgical injury. Artif Cells Blood Substit Biotechnol 37:117-124. https://doi.org/10.1080/10731190902916380

69. Nouhi S, Ahrens L, Pereira HC, Hughes AV, Campana M, Gutfreund P, Palsson GK, Vorobiev A, Hellsing MS (2018) Interactions of perfluoroalkyl substances with a phospholipid bilayer studied by neutron reflectometry. J Colloid Interface Sci 511:474-481. https://doi.org/10.1016/j.jcis.2017.09.102

70. Obratsov VV, Grishanova A, Gudkova OV, Shekhtman DG (1992) Mechanism of inhibiting the cytochrome P-450 dependent monooxygenase system in liver with fluorocarbons. Biokhimiia 57:1011-1020

71. Obraztsov VV, Shekhtman D (1994) Effect of perfluorochemicals on liver detoxication enzymes. Artif Cells Blood Substit Biotechnol 22:1259-1266. https://doi.org/10.3109/ 10731199409138824

72. Obraztsov VV, Neslund GG, Kornbrust ES, Flaim SF, Woods CM (2000) In vitro cellular effects of perfluorochemicals correlate with their lipid solubility. Am J Phys Lung Cell Mol Phys 278: 
L1018-L1024. https://doi.org/10.1152/ajplung.2000.278.5. L1018

73. Obraztsov VV, Shekhtman DG, Sklifas AN, Makarov KN (1988) Analysis of the physico-chemical properties of fluorocarbon inducers of cytochrome P-450 in membranes of liver endoplasmic reticulum. Biokhimiia 53:613-619

74. Ohyanagi H, Nakaya S, Okumura S, Saitoh Y (1984) Surgical use of Fluosol-DA in Jehovah's witness patients. Artif Organs 8:10 18. https://doi.org/10.1111/j.1525-1594.1984.tb04238.x

75. Okamoto H, Yâmanouchi K, Yokoyama K (1975) Retention of perfluorochemicals in circulating blood and organs of animals after intravenous injection of their emulsions. Chem Pharm Bull 23:1452-1457. https://doi.org/10.1248/cpb.23.1452

76. Okumura S, Uemura T, Zhao X, Masano Y, Tsuruyama T, Fujimoto Y, Iida T, Yagi S, Bezinover D, Spiess B (2017) Liver graft preservation using perfluorocarbon improves the outcomes of simulated donation after cardiac death liver transplantation in rats. Liver Transpl 23:1171-1185. https://doi.org/10.1002/1t. 24806

77. Oleksiak CB, Habif SS, Rosano HL (1994) Flocculation of perfluorocarbon emulsions. Colloids Surf A Physicochem Eng Asp 84:71-79

78. Perevedentseva E, Zaritskiy A, Fok M, Kuznetsova I (1998) Perfluorocarbon emulsions increase transfer of oxygen in plasma from erythrocyte to tissues. Artif Cells Blood Substit Biotechnol 26:223-229. https://doi.org/10.3109/10731199809119780

79. Perkkiö J, Keskinen R (1983) Hematocrit reduction in bifurcations due to plasma skimming. Bull Math Biol 45:41-50. https://doi. org/10.1007/BF02459386

80. Police AM, Waxman K, Tominaga G (1985) Pulmonary complications after Fluosol administration to patients with lifethreatening blood loss. Crit Care Med 13:96-98. https://doi.org/ 10.1097/00003246-198502000-00008

81. Powell KC, Damitz R, Chauhan A (2017) Relating emulsion stability to interfacial properties for pharmaceutical emulsions stabilized by Pluronic F68 surfactant. Int J Pharm 521:8-18. https://doi. org/10.1016/j.ijpharm.2017.01.058

82. Rafikova O, Sokolova E, Rafikov R, Nudler E (2004) Control of plasma nitric oxide bioactivity by perfluorocarbons: physiological mechanisms and clinical implications. Circulation 110:35733580. https://doi.org/10.1161/01.CIR.0000148782.37563.F8

83. Riess JG, Le Blanc M (1982) Solubility and transport phenomena in perfluorochemicals relevant to blood substitution and other biomedical applications. Pure Appl Chem 54:2383-2406. https://doi. org/10.1351/pac198254122383

84. Rosenblum W, Hadfield M, Martinez A, Schatzki P (1976) Alterations of liver and spleen following intravenous infusion of fluorocarbon emulsions. Arch Pathol Lab Med 100:213-217

85. Scholz R, Hansen W, Thurman RG (1973) Interaction of mixedfunction oxidation with biosynthetic processes: 1. Inhibition of gluconeogenesis by aminopyrine in perfused rat liver. Eur $\mathbf{J}$ Biochem 38:64-72. https://doi.org/10.1111/j.1432-1033.1973. tb03034.x

86. Shimizu S, Enoki Y, Kohzuki H, Ohga Y, Sakata S (1986) Determination of Hüfner's factor and inactive hemoglobins in human, canine, and murine blood. Jpn J Physiol 36:1047-1051. https://doi.org/10.2170/jjphysiol.36.1047

87. Sloviter HA, Kamimoto T (1967) Erythrocyte substitute for perfusion of brain. Nature 216:458-460. https://doi.org/10.1038/ $216458 \mathrm{a} 0$

88. Smart BE (1994) Characteristics of CF systems. In: Organofluorine chemistry. Springer, pp. 57-88. doi:https://doi. org/10.1007/978-1-4899-1202-2_3
89. Song G, Ji C, Liang C, Song X, Yi X, Dong Z, Yang K, Liu Z (2017) $\mathrm{TaOx}$ decorated perfluorocarbon nanodroplets as oxygen reservoirs to overcome tumor hypoxia and enhance cancer radiotherapy. Biomaterials 112:257-263. https://doi.org/10.1016/j. biomaterials.2016.10.020

90. Spiess BD (2009) Perfluorocarbon emulsions as a promising technology: a review of tissue and vascular gas dynamics. J Appl Physiol 106:1444-1452. https://doi.org/10.1152/japplphysiol. 90995.2008

91. Strom J, Swyers T, Wilson D, Unger E, Chen QM, Larson DF (2014) Dodecafluoropentane emulsion elicits cardiac protection against myocardial infarction through an ATP-Sensitive K+ channel dependent mechanism. Cardiovasc Drugs Ther 28:541-547. https://doi.org/10.1007/s10557-014-6557-2

92. Swyer T, Strom J, Larson DF (2014) Nanoparticle oxygen delivery to the ischemic heart. Perfusion 29:539-543. https://doi.org/ $10.1177 / 0267659114534290$

93. Tadros T, Izquierdo P, Esquena J, Solans C (2004) Formation and stability of nano-emulsions. Adv Colloid Interf Sci 108-109:303318. https://doi.org/10.1016/j.cis.2003.10.023

94. Truesdale G, Downing A (1954) Solubility of oxygen in water. Nature 173:1236-1236. https://doi.org/10.1038/1731236a0

95. Tsuda Y, Nakura K, Yamanouchi K, Yokoyama K, Watanabe M, Ohyanagi H, Saitoh Y (1989) Study of the excretion mechanism of a perfluorochemical emulsion. Artif Organs 13:197-203. https://doi.org/10.1111/j.1525-1594.1989.tb02863.x

96. Ullrich V, Diehl H (1971) Uncoupling of monooxygenation and electron transport by flurocarbons in liver microsomes. Eur J Biochem 20:509-512. https://doi.org/10.1111/j.1432-1033.1971. tb01420.x

97. Urbanellis P, Hamar M, Kaths JM, Kollmann D, Linares I, Mazilescu L, Ganesh S, Wiebe A, Yip PM, John R, Konvalinka A, Mucsi I, Ghanekar A, Bagli DJ, Robinson LA, Selzner M (2020) Normothermic ex vivo kidney perfusion improves early DCD graft function compared with hypothermic machine perfusion and static cold storage. Transplantation 104:947-955. https:// doi.org/10.1097/tp.0000000000003066

98. Vemuri C, Upadhya GA, Arif B, Jia J, Lin Y, Gaut JP, Fazal J, Pan H, Wickline SA, Chapman WC (2018) Antithrombin perfluorocarbon nanoparticles improve renal allograft function in a murine deceased criteria donor model. Transplant Direct 4. doi:https://doi. org/10.1097/TXD.0000000000000817

99. Venegas B, Wolfson MR, Cooke PH, Chong PL-G (2008) High vapor pressure perfluorocarbons cause vesicle fusion and changes in membrane packing. Biophys J 95:4737-4747. https://doi.org/ 10.1529/biophysj.108.133496

100. Viktor V, Moroz AMC, Elena K, Kozlova (2020) Coronavirus SARS-CoV-2: hypotheses of impact on the circulatory system, prospects for the use of perfluorocarbon emulsion, and feasibility of biophysical research methods. General Reanimatology. https:// doi.org/10.15360/1813-9779-2020-3-0-1

101. Vorob'ev S (2009) First-and second-generation perfluorocarbon emulsions. Pharm Chem J 43:209-218. https://doi.org/10.1111/j. 1423-0410.1991.tb00888.x

102. Wesseler EP, Iltis R, Clark LC Jr (1977) The solubility of oxygen in highly fluorinated liquids. J Fluor Chem 9:137-146. https://doi. org/10.1016/S0022-1139(00)82152-1

103. Wrobeln A, Jägers J, Quinting TS, Timm, Kirsch M, Fandrey J, Ferenz KB (2020) Albumin-derived perfluorocarbon-based artificial oxygen carriers can avoid hypoxic tissue damage in massive hemodilution. Sci Rep (Nature Publisher Group) 10. doi:https:// doi.org/10.1038/s41598-020-68701-z

104. Wrobeln A, Kirsch M, Ferenz KB (2017) Improved albuminderived perfluorocarbon-based artificial oxygen carriers: in-vivo 
evaluation of biocompatibility. Adv Biotech \& Micro 7. Doi: https://doi.org/10.19080/aibm.2017.07.555714

105. Wrobeln A, Laudien J, Gross-Heitfeld C, Linders J, Mayer C, Wilde B, Knoll T, Naglav D, Kirsch M, Ferenz KB (2017) Albumin-derived perfluorocarbon-based artificial oxygen carriers: a physico-chemical characterization and first in vivo evaluation of biocompatibility. Eur J Pharm Biopharm 115:52-64. https://doi. org/10.1016/j.ejpb.2017.02.015

106. Wrobeln A, Schluter KD, Linders J, Zahres M, Mayer C, Kirsch M, Ferenz KB (2017) Functionality of albumin-derived perfluorocarbon-based artificial oxygen carriers in the Langendorff-heart (dagger). Artif Cells Nanomed Biotechnol 45:723-730. https:// doi.org/10.1080/21691401.2017.1284858
107. Xiang Y, Bernards N, Hoang B, Zheng J, Matsuura N (2019) Perfluorocarbon nanodroplets can reoxygenate hypoxic tumors in vivo without carbogen breathing. Nanotheranostics 3:135144. https://doi.org/10.7150/ntno.29908

108. Yokoyama K (1978) Effect of perfluorochemical (PFC) emulsion on acute carbon monoxide poisoning in rats. Jpn J Surg 8:342 352. https://doi.org/10.1007/BF02469417

109. Zhu J, Hullett J, Somera L, Barbee R, Ward K, Berger B, Spiess B (2007) Intravenous perfluorocarbon emulsion increases Nitrogen washout after venous gas emboli in rabbits doi: 17393935

Publisher's note Springer Nature remains neutral with regard to jurisdictional claims in published maps and institutional affiliations. 